\title{
Effects of rearing density and sub-sand filters on growth performance of juvenile freshwater mussels (Chamberlainia hainesiana) reared under recirculating system conditions
}

\author{
Satit Kovitvadhi ${ }^{\mathrm{a}}$, Uthaiwan Kovitvadhi ${ }^{\mathrm{b}, *}$ \\ ${ }^{a}$ Department of Agriculture, Faculty of Science and Technology, Bansomdejchaopraya Rajabhat University, \\ Bangkok 10600 Thailand \\ b Department of Zoology, Faculty of Science, Kasetsart University, Bangkok 10900 Thailand
}

${ }^{*}$ Corresponding author, e-mail: fsciutk@ku.ac.th

Received 26 Jul 2012

Accepted 26 Dec 2012

\begin{abstract}
Chamberlainia hainesiana, a commercially valuable bivalve, is found in Thailand. Juveniles of $C$. hainesiana have been successfully cultured in sterilized artificial media for culturing glochidia (to bypass the parasitic stage) until they develop into the juvenile stage. The survival percentage of glochidia in standard tissue culture medium (M199) supplemented with common carp plasma and antibiotics/antimycotic was $97.2 \pm 2.5 \%$. All surviving larvae (100\%) ultimately transformed into juveniles within 8 days. Early juveniles (0-90 days old) were reared in recirculating systems and were cultured at three density levels $(500,1500$, and 3000 per culture unit) in a laboratory. The density level of 500 per culture unit resulted in the highest and most significant $(p<0.05)$ growth rate, with an average shell length and shell height; the average survival was $71.3 \pm 0.4 \%$. The 90-150-day-old juveniles were reared outdoors in two different systems (with and without a filter plate). They were fed by filtering phytoplankton from the water in an earthen pond. The filter-plate system produced the highest growth rate $(p<0.01)$, with an average weight gain and shell size; the average survival was $98.7 \pm 0.6 \%$. A forecasting equation was used to describe the shell length of juveniles, i.e., the relationship between shell length $(L, \mathrm{~mm})$ and age $(t$, days). The equations for 0-90-day-old early juveniles cultured in the laboratory (500 per culture unit), and for 90-150-day-old juveniles cultured using system 1 were $L=0.5236-0.053 t+0.0023 t^{2}-1 \times 10^{-5} t^{3}\left(r^{2}=0.956\right)$ and $L=-51.302+0.6812 t-5 \times 10^{-6} t^{3}\left(r^{2}=0.940\right)$, respectively.
\end{abstract}

KEYWORDS: stocking density, sub-sand system, culture, Unionidae

\section{INTRODUCTION}

Chamberlainia hainesiana (Lea, 1856) is the largest freshwater pearl mussel. It is endemic throughout Thailand, and thus possesses great potential as a source of production of cultured pearls ${ }^{1,2}$. The mussel's nacreous shell can be used for inlaying pearl furniture, ornaments, kitchen utensils, and souvenirs. These mussels are suspension feeders, and their filtration activities also contribute to maintain a clean aquatic environment and to reduce pollution. Freshwater pearl culturing techniques are generally considered to be a highly successful achievement; however the number of mussels all over the world is drastically decreasing, and some species are nearly extinct. This is due to deterioration of water resources as well as overutilization/overconsumption of mussels, as has occurred in several countries around the world ${ }^{3-5}$, including the case of $C$. hainesiana. For these reasons, it is of utmost importance to support sustainable culture in the mussel industry, and to establish effective conservation measures for their continued future use.

The culture of freshwater pearl mussels is divided into three steps that follow the life cycle of the mussel: parasitic glochidial stage, juvenile stage, and adult. At present, juvenile freshwater mussels have been successfully cultured in the laboratory by attaching glochidia to fish (infestation) until they reach the juvenile stage ${ }^{6-10}$. Moreover, it is possible to use sterilized artificial media for successfully culturing glochidia bypassing the parasitic stage ${ }^{11-23}$. However, glochidial infestation of fish results in high juvenile mortality due to the disturbance caused by bacteria, protozoa, and contaminating fungi ${ }^{13}$. But using of artificial media for glochidia culture can achieve high production as well as prevent contamination ${ }^{11-23}$. A recent report described the use of artificial media to successfully culture glochidia of the freshwater 
pearl mussel Hyriopsis (Limnoscapha) myersiana to the juvenile stage ${ }^{17}$. A sub-sand filter is commonly used to remove particulate matter, and to convert and ultimately remove nitrogenous compounds from the water in an aquaculture system by means of biological oxidation and reduction ${ }^{24}$. In this system, water containing high dissolved oxygen flows through the sub-sand filter; bacteria attached to the sand particles could convert ammonia nitrogen from aquatic animal excretion into nitrite and nitrate, respectively. This results in less ammonia toxicity to aquatic animals, and increases growth and survival.

Therefore, this study aimed to develop an effective culturing technique for $C$. hainesiana, with the goal of achieving high yield in to promote freshwater pearl mussel culture on a commercial scale, as well as to promote conservation by sustainable use. The growth and survival rates were compared for: 0-90day-old juveniles reared at three different densities; and 90-150-day-old juveniles cultured with and without the use of a sub-sand filter system

\section{MATERIALS AND METHODS}

\section{Culture of glochidia}

Ten male and ten female adult freshwater mussels, C. hainesiana, were cultured on a raft in the Mae Klong Reservoir at the Kanchanaburi Inland Fisheries Research and Development Centre, Department of Fisheries, Kanchanaburi province, Thailand. These individuals had an average weight of $221 \pm 64 \mathrm{~g}$, length of $11.4 \pm 0.3 \mathrm{~cm}$, width of $3.9 \pm 0.5 \mathrm{~cm}$, and height of $6.2 \pm 0.2 \mathrm{~cm}$. Mature glochidia were aspirated from gravid mussels and transferred to artificial culture medium ${ }^{15}$. Approximately 5000-6000 glochidia/replication (three replicates) were placed in a culture dish $(90 \mathrm{~cm} \times 15 \mathrm{~mm})$ containing: $10 \mathrm{ml}$ of artificial medium composed of M199 (Gibco, No. 6231100-035); fish plasma (common carp, Cyprinus carpio); and antibiotics/antimycotic $(100 \mu \mathrm{g} / \mathrm{ml} \mathrm{car-}$ benicillin, $100 \mu \mathrm{g} / \mathrm{ml}$ gentamicin sulphate, $100 \mu \mathrm{g} / \mathrm{ml}$ rifampin, and $5 \mu \mathrm{g} / \mathrm{ml}$ amphotericin B) in a ratio of 2:1:0.5, respectively. The culture dishes were placed in a low-temperature incubator at $25^{\circ} \mathrm{C}$ with $5 \% \mathrm{CO}_{2}$. The culture medium was removed and replaced with fresh medium on day 4 . Finally, $4 \mathrm{ml}$ of sterilized distilled water was added to the culture dish on day 7 to stimulate the transformation of glochidia into juveniles.

\section{Culture of 0-90-day-old juveniles}

Newly transformed juveniles were removed from the artificial medium and rinsed in dechlorinated aerated water ${ }^{15}$. Samples of cultured 0-day-old (newborn) juveniles were transferred to plastic culture units (width $\times$ length $\times$ height $=11 \mathrm{~cm} \times 20 \mathrm{~cm} \times 8 \mathrm{~cm}$, water level $=7 \mathrm{~cm})$ at three density levels $(500$, 1500, and 3000 juveniles per culture unit). There were three replicates of each density, and each culture unit contained $20 \mathrm{~g}$ of sand $(<120 \mu \mathrm{m}$ grain size $)$ about $3 \mathrm{~mm}$ thick. They were reared in closed recirculating culture systems, and were fed twice daily (at 06:00 and 18:00 h) with a combination of Chlorella sp. and Kirchneriella incurvata in a ratio of $1: 1$ at a concentration of $1 \times 10^{5}$ cells $/ \mathrm{ml}^{17}$. This system comprised three filter cabinets: a particulate filter cabinet, a macrophyte filter cabinet, and a biological filter cabinet. Water flowed through the particulate filter cabinet and then, via the second part, to the macrophyte filters cabinet. The water then flowed into the biological filter cabinet filled with BioBall (BioMérieux Industry) and then to the resting cabinet. The water from the resting cabinet was pumped at $20 \mathrm{ml} / \mathrm{min}$ into a plastic culture unit. The water circulation was turned off for $1 \mathrm{~h}$ during feeding. The mussels were sampled by isolating juveniles from the sand by screening (with $120 \mu \mathrm{m}$ mesh) every 10 days for growth study during the experiment; juveniles comprised $n=50$ from each culture unit. Growth of juveniles was assessed by recording increments of shell size (shell length and height). Juveniles were measured using a light microscope with a calibrated ocular micrometer to the nearest $0.01 \mathrm{~mm}$. Growth rates were calculated as average growth rate in $\mathrm{mm} /$ day (average shell length or average shell height at the end of every 10-day period), and average shell length or average shell height before the initial 10day total growth period. Survival was calculated by using the average number of living juveniles at the beginning of the experiment and at the end of every 10-day period.

\section{Culture of 90-150-day-old juveniles}

Samples of 90-day-old juveniles were reared in two systems for comparison of growth and survival. System 1 (Fig. 1a) consisted of two parts. The first part had dimensions of width $\times$ length $\times$ height $=$ $50 \mathrm{~cm} \times 80 \mathrm{~cm} \times 120 \mathrm{~cm}$, water level $=80 \mathrm{~cm}$, and was overlaid with an acrylic plate $(6 \mathrm{~mm}$ thick and with holes $3 \mathrm{~mm}$ in diameter throughout the plate) $10 \mathrm{~cm}$ above the cabinet floor. The second part, with corresponding dimensions of $50 \mathrm{~cm} \times 20 \mathrm{~cm} \times 120 \mathrm{~cm}, 80 \mathrm{~cm}$ water, was used to contain the water outflow from the rearing cabinet into an earthen pond. System 2 (Fig. 1b) had the same configuration as system 1 except for the acrylic 

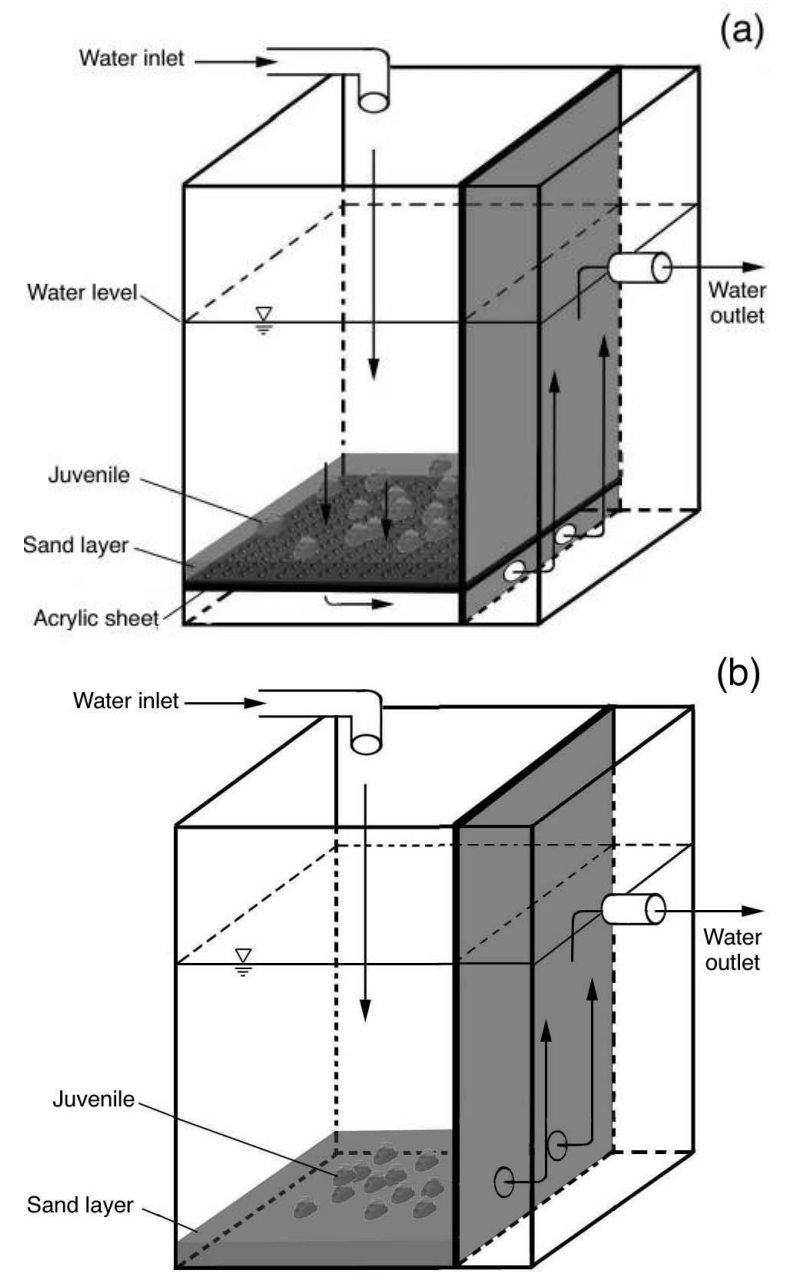

Fig. 1 Schematic diagram of the recirculating system 1 (a, with a filter plate) and 2 (b, without a filter plate) used to rear freshwater pearl mussel juveniles (90-150 days). Arrows show water current.

plate. Both systems were filled to $5 \mathrm{~cm}$ depth with sand ( $>4 \mathrm{~mm}$ grain size) on the plate and on the cabinet floor. A total of 2000 juveniles were cultured using both systems $\left(0.4\right.$ juveniles $\left./ \mathrm{cm}^{2}\right)$. Water for rearing juveniles in both systems was pumped from an earthen pond about 2 acres in size, at the Department of Aquaculture, Faculty of Fisheries, Kasetsart University. The water flow rate was $3 \mathrm{l} / \mathrm{min}$, and air was supplied to the juvenile culturing cabinets $24 \mathrm{~h}$ per day. There were three replicates. Fifty juveniles were randomly sampled every 20 days to measure shell length, height, and width, and to count the number of surviving juveniles.

\section{Water analysis}

Water quality analysis of cultured juveniles in the laboratory (0-90 days) was also performed in the two culture systems (90-150 days) every 10 and 20 days, respectively. Measurements were taken of water temperature (Hg thermometer), turbidity (nephelometric method), conductivity (conductivity meter), $\mathrm{pH}$ (pH meter), dissolved oxygen (azide modification), free $\mathrm{CO}_{2}$ (titration), total alkalinity (phenolphthalein methyl orange indicator), total hardness (EDTA titration), total ammonia nitrogen (phenate method), nitrite (colorimetry), nitrate (cadmium reduction), phosphorus (ascorbic acid method), silica (molybdosilicate method), and calcium (EDTA titration) ${ }^{25}$.

\section{Phytoplankton communities}

Sampling of phytoplankton in the two culture systems (90-150 days) was performed in 101 culture cabinets. There were three replicates/cabinet. Samples were analysed for species and quantities of phytoplankton every 20 days. Samples of phytoplankton were screened through a $20 \mu \mathrm{m}$ plankton net and preserved in a solution of $1 \%$ acidic Lugol's solution. Sampling was also conducted by counting species of phytoplankton under an inverted microscope. Species identification was based on taxonomy of phytoplankton $^{26-28}$. All samples were examined in triplicate.

\section{Statistical analysis}

Comparison of growth rate (length and height of shell) and survival in each level of density (500, 1500 , and 3000 per culture unit) in 0-90 days old juvenile using experimental design (one-way analysis) every 10 days and comparison of average values using Duncan's Multiple Range Test (DMRT) at a 0.05 significance level were implemented. For 90-150day-old juveniles, growth rate (weight, length, height and width of shell), survival of juveniles and water quality between system 1 and 2 using experimental design ( $t$-test) every 20 days were compared. The coefficient of correlation $\left(r^{2}\right)$ of linear regression was used in relationship of juvenile during 0-90 days old which was calculated by using average of water quality characteristics with average survival or average shell length. When 90-150 days old juvenile, coefficient of correlation between average of water quality characteristics and average survival or average shell length or average weight was compared.

The relationship between ages (0-90 and 90-150 days old) with shell length was expressed by the equation: $L=b_{0}+b_{1} t+b_{2} t^{2}+b_{3} t^{3}$, where $L$ is the shell length (in mm), $t$ is age (in days), 
Table 1 Average growth rate and survival of 0-90 days in the laboratory.

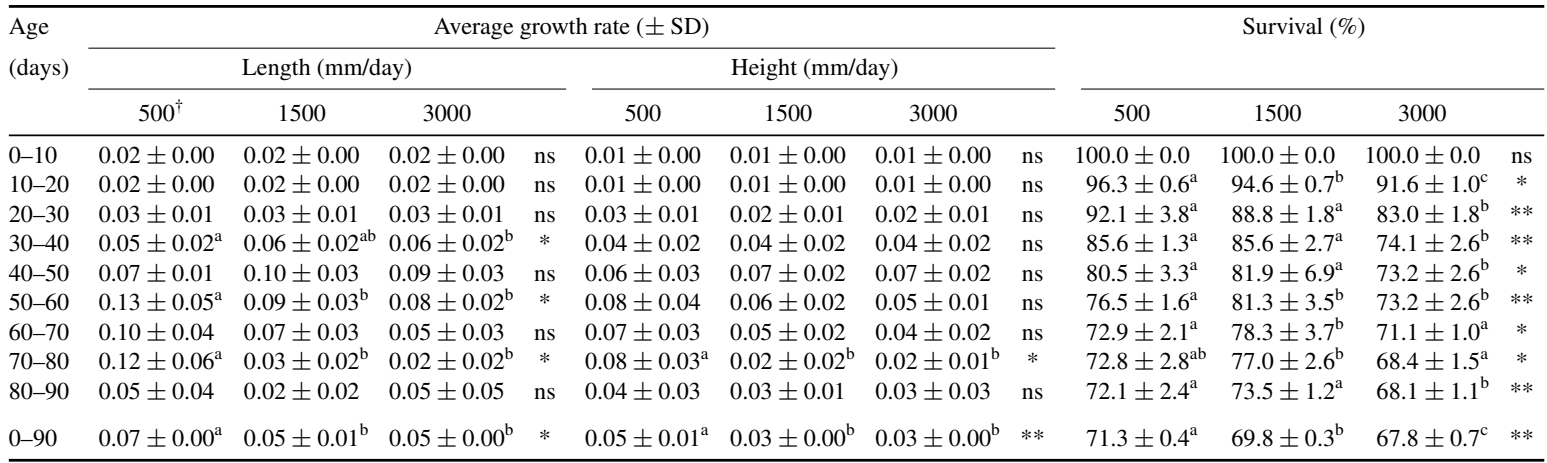

$\dagger$ Number of juveniles per culture unit.

Different letters within a row indicate significant difference; $*=p<0.05, * *=p<0.01$, ns $=$ no significant difference $(p>0.05)$.

and $b_{0}, b_{1}, b_{2}$, and $b_{3}$ are parameters. The all group comparison and regressions analysis was used the statistical program SPSS (SPSS Inc.).

\section{Morphological development of $C$. hainesiana}

The living mussels were collected in sequential developmental stages between 0 and 150 days old. Morphological development was observed by light microscope (0-90 days old) and photography with a digital camera (110-150 days old).

\section{RESULTS}

\section{Culture of glochidia}

The glochidia of $C$. hainesiana were completely transformed within 8 days, with a survival rate of $97.2 \pm 2.5 \%$. All surviving larvae transformed into the juvenile stage. The average shell length and height were $0.26 \pm 0.04 \mathrm{~mm}$.

\section{Culture of 0-90-day-old juveniles}

Juveniles (0-90 days old) cultured at a density of 500 juveniles/culture unit had the highest growth of shell length, with a significant difference $(p<0.05)$ compared with densities of 1500 and 3000 juveniles per culture (Fig. 2a and Table 1).

\section{Culture of 90-150-day-old juveniles}

Juveniles cultured in system 1 (with a sub-sand filter) produced greater shell length than those cultured in system 2 (without a sub-sand filter), with a significant difference $(p<0.05)$. At the termination of the experiment (Fig. 2b), both groups had the same average growth rate (90-150 days) in terms of weight, shell length, shell height, and shell width. However, there was no significant difference in the survival rates between the two systems $(p>0.05)$ (Table 2).
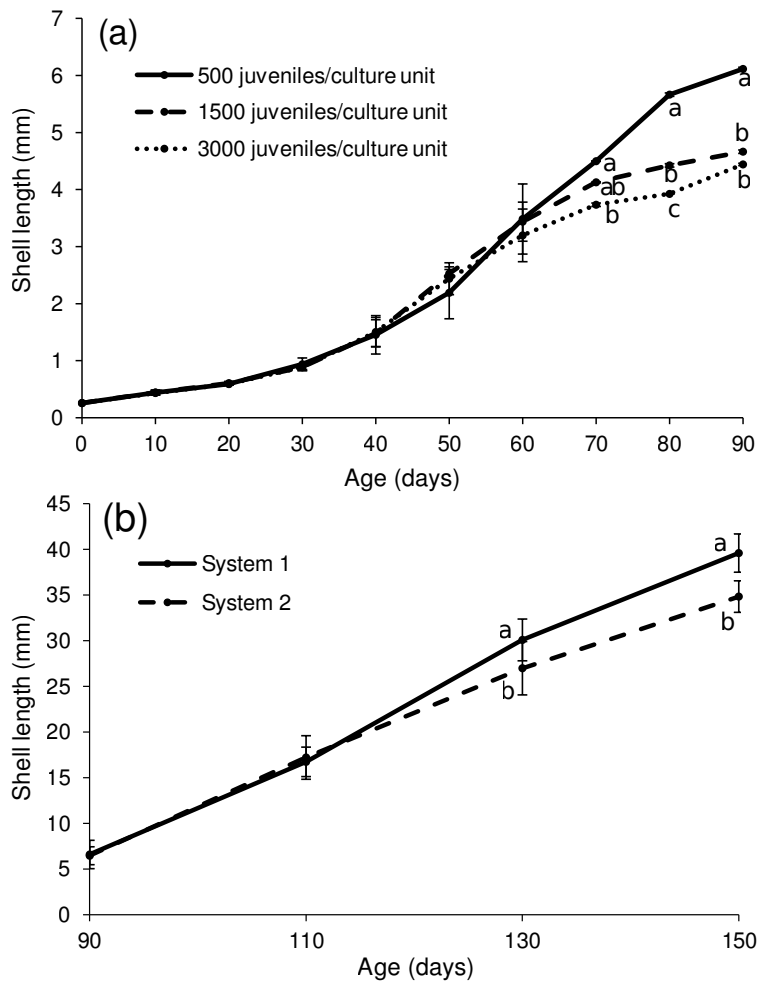

Fig. 2 Development of $C$. hainesiana juveniles. Average shell length $( \pm \mathrm{SD})$ of (a) 0-90-day-old juveniles cultured at different densities and (b) 90-150-day-old juveniles cultured in system 1 (with a filter plate) and 2 (without a filter plate). Different letters at each age within each density and system denote significantly different value $(p<0.05)$.

\section{Water quality}

Average water quality throughout the culture of $0-150$-day-old mussels is shown in Table 3 . In a comparison of water quality between systems 1 and 
Table 2 Average growth rate and survival of 90-150 days cultured in system 1 and 2 .

\begin{tabular}{|c|c|c|c|c|c|c|c|c|c|c|}
\hline \multirow{3}{*}{$\begin{array}{l}\text { Age } \\
\text { (days) }\end{array}$} & \multicolumn{8}{|c|}{ Average growth rate $( \pm \mathrm{SD})$} & \multicolumn{2}{|c|}{ Survival (\%) } \\
\hline & \multicolumn{2}{|c|}{ Weight (g/day) } & \multicolumn{2}{|c|}{ Length (mm/day) } & \multicolumn{2}{|c|}{ Height (mm/day) } & \multicolumn{2}{|c|}{ Width (mm/day) } & & \\
\hline & System 1 & System 2 & System 1 & System 2 & System 1 & System 2 & System 1 & System 2 & System 1 & System 2 \\
\hline$\overline{90-11}$ & $0.01 \pm 0.00$ & $0.02 \pm 0.00^{\mathrm{ns}}$ & $0.50 \pm$ & $0.08^{\mathrm{ns}}$ & $0.30 \pm 0.01$ & $0.39 \pm 0.06^{\mathrm{ns}}$ & $0.12 \pm 0.00$ & $0.15 \pm 0.02^{\mathrm{ns}}$ & $100.0 \pm 0.0$ & $100.0 \pm 0.0^{\mathrm{ns}}$ \\
\hline $110-130$ & $0.11 \pm 0.02$ & $0.12 \pm 0.02^{\mathrm{ns}}$ & $0.66 \pm 0.03$ & $0.48 \pm 0.03^{* *}$ & $0.53 \pm 0.01$ & $0.43 \pm 0.03^{*}$ & $0.21 \pm 0.01$ & $0.15 \pm 0.01^{* *}$ & $99.4 \pm 0.3$ & $98.5 \pm 0.9^{\text {ns }}$ \\
\hline $130-150$ & $0.19 \pm 0.02$ & $0.13 \pm 0.00^{* *}$ & $0.47 \pm 0.03$ & $0.39 \pm 0.06^{\mathrm{ns}}$ & $0.38 \pm 0.03$ & $0.34 \pm 0.04^{\mathrm{ns}}$ & $0.19 \pm 0.01$ & $0.15 \pm 0.02^{* *}$ & $99.0 \pm 0.6$ & $97.7 \pm 0.8^{\mathrm{ns}}$ \\
\hline $90-150$ & $0.10 \pm 0.01$ & $0.08 \pm 0.01^{* *}$ & $0.55 \pm 0.01$ & $0.47 \pm 0.01^{* *}$ & $0.44 \pm 0.00$ & $0.39 \pm 0.17^{*}$ & $0.17 \pm 0.00$ & $0.15 \pm 0.00^{*}$ & $98.7 \pm 0.6$ & $96.8 \pm 0.8^{\mathrm{ns}}$ \\
\hline
\end{tabular}

$*=p<0.05, * *=p<0.01, \mathrm{~ns}=$ not significant difference $(p>0.05)$ between systems 1 and 2 .

Table 3 Average \pm SD of water quality parameters during culture over $0-150$ days.

\begin{tabular}{|c|c|c|c|c|}
\hline \multirow[t]{2}{*}{ Parameters } & \multirow[t]{2}{*}{ 0-90 days old } & \multicolumn{3}{|c|}{ 90-150 days old } \\
\hline & & System 1 & System 2 & \\
\hline Water temp. $\left({ }^{\circ} \mathrm{C}\right)$ & $25.0 \pm 0.0$ & $30 \pm 10$ & $30.1 \pm 1.1$ & ns \\
\hline Turbi & - & $9.8 \pm 1.1$ & 9.0 & ns \\
\hline Conductivity $(\mu S)$ & $269.7 \pm 3.2$ & $355 \pm 21$ & $357 \pm 18$ & ns \\
\hline $\mathrm{pH}$ & $7.86 \pm 0.12$ & $7.63 \pm 0.16$ & $7.42 \pm 0.25$ & ns \\
\hline $\begin{array}{l}\text { Dissolved oxygen } \\
\left(\mathrm{ppm} \mathrm{O}_{2}\right)\end{array}$ & $7.3 \pm 0.4$ & $=0.20$ & 0.31 & ( \\
\hline $\begin{array}{l}\text { Free } \mathrm{CO}_{2} \\
\left(\mathrm{ppm} \mathrm{CO}_{2}\right)\end{array}$ & $3.5 \pm 0.8$ & $10.2 \pm 1.2$ & $10.9 \pm 2.1$ & ns \\
\hline $\begin{array}{l}\text { Total alkalinity } \\
\left(\mathrm{ppm} \mathrm{CaCO}_{3}\right)\end{array}$ & $74 \pm 8$ & $51.5 \pm 3.0$ & $53.1 \pm 3.2$ & ns \\
\hline $\begin{array}{l}\text { Total hardness } \\
\left(\mathrm{ppm} \mathrm{CaCO}_{3}\right)\end{array}$ & $124 \pm 9$ & $246 \pm 15$ & $236 \pm 7$ & $*$ \\
\hline $\begin{array}{l}\text { Total ammonia } \mathrm{N} \\
\left(\mathrm{ppm} \mathrm{NH}_{3}-\mathrm{N}\right)\end{array}$ & $0.07 \pm 0.03$ & $0.18 \pm 0.06$ & $0.24 \pm 0.08$ & $* *$ \\
\hline $\begin{array}{l}\text { Nitrite } \\
\left(\mathrm{ppm} \mathrm{NO} \mathrm{NO}_{-}^{-}-\mathrm{N}\right)\end{array}$ & $0.007 \pm 0.004$ & $0.013 \pm 0.006$ & $0.014 \pm 0.011$ & ns \\
\hline $\begin{array}{l}\text { Nitrate } \\
\left(\mathrm{ppm} \mathrm{NO}_{3}^{-}-\mathrm{N}\right)\end{array}$ & $0.22 \pm 0.09$ & $0.024 \pm 0.018$ & $0.017 \pm 0.017$ & $*$ \\
\hline $\begin{array}{l}\text { Phosphorus } \\
\text { (ppm P) }\end{array}$ & $0.005 \pm 0.016$ & $0.004 \pm 0.002$ & $0.004 \pm 0.002$ & ns \\
\hline Silica (ppm $\left.\mathrm{SiO}_{2}\right)$ & $4.9 \pm 0.9$ & $18.3 \pm 2.1$ & $18.0 \pm 2.1$ & ns \\
\hline $\begin{array}{l}\text { Calcium } \\
\left(\mathrm{ppm} \mathrm{CaCO}_{3}\right)\end{array}$ & $74+4$ & $104+7$ & $104 \pm$ & ns \\
\hline
\end{tabular}

$*=p<0.05, * *=p<0.01, \mathrm{~ns}=$ not significant difference $(p>0.05)$ between system 1 and 2 .

2 (90-150 days), it was found that water quality mostly exhibited no significant difference $(p>0.05)$, except that total hardness and nitrate had significant difference $(p<0.05)$, total ammonia nitrogen had a highly significant difference $(p<0.01)$. Culture of mussels in the laboratory (0-90 days) revealed that both survival and shell length had highly significant relationships $(p<0.01)$ with ammonia nitrogen, nitrate, silica, and calcium (Table 4). In comparing the culture of mussels between the two systems (90-150 days), it was found that survival, total weight and shell length had an inverse relationship with total hardness and silica, respectively.

\section{Phytoplankton community}

Based on average total phytoplankton quantities in the two systems, it was found that there were greater quantities of phytoplankton in system 1 than in system 2 , with a significant difference $(p<0.05)$ on days 110 and 150 (Fig. 3). The percentages of types

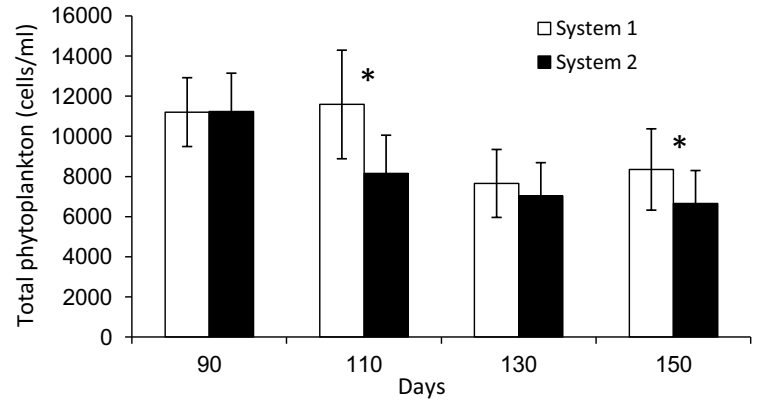

Fig. 3 Comparison of total of phytoplankton (cells $/ \mathrm{ml}$ ) between system 1 and 2 during 90-150-day-old cultures. (*) Indicated total of phytoplankton of system 1 which was different from system 2 of the same day $(*=p<0.05)$.

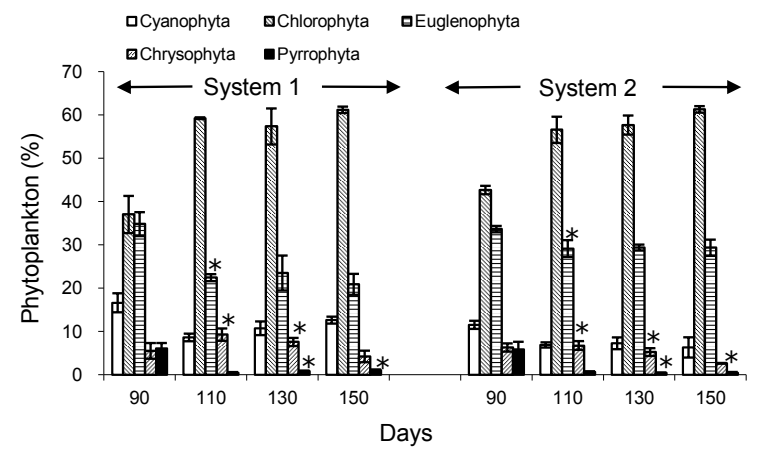

Fig. 4 Percentage of phytoplankton in each division between 90-150-day-old cultures in system 1 and 2. (*) Indicated percentage of phytoplankton in the same division of system 1 which was different from system 2 of the same day $(*=p<0.05)$.

of phytoplankton that were found between the two culture systems determined that the division Chlorophyta was most prevalent, followed by Euglenophyta, Cyanophyta, Chrysophyta, and Pyrrophyta, respectively (Fig. 4). 
Table 4 Coefficients of correlation between average survival and water quality parameters, and average growth and water quality parameters of juveniles over 0-90 and 90-150 days.

\begin{tabular}{|c|c|c|c|c|c|c|c|c|c|c|c|c|c|c|}
\hline & 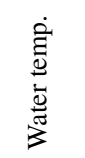 & 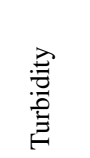 & 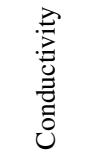 & I & ஜ & 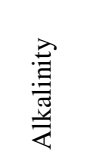 & $0^{N}$ & ت્ّ & 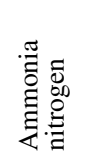 & 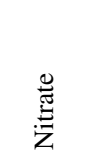 & $\stackrel{\stackrel{\mathscr{E}}{\Xi}}{\text { 艺 }}$ & 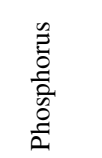 & 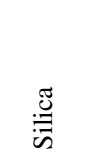 & $\frac{\Xi}{\frac{0}{0}}$ \\
\hline \multicolumn{15}{|c|}{ 0-90 days } \\
\hline $\begin{array}{l}\text { Survival } \\
500^{\dagger}\end{array}$ & 0.03 & - & 0.28 & -0.15 & 0.58 & -0.00 & -0.37 & $0.63^{*}$ & $0.88^{* *}$ & $0.93^{* *}$ & -0.23 & 0.39 & $-0.79^{* * *}$ & $0.94^{* *}$ \\
\hline 1500 & 0.30 & - & 0.26 & -0.09 & $0.63^{*}$ & 0.03 & -0.37 & $0.66^{*}$ & $0.81^{* *}$ & $0.89^{* *}$ & -0.29 & 0.27 & $-0.8^{* *}$ & $0.92^{* * *}$ \\
\hline 3000 & 0.50 & - & 0.16 & -0.00 & $0.62^{*}$ & 0.15 & -0.35 & 0.53 & $0.76^{* *}$ & $0.80^{* *}$ & -0.21 & 0.25 & $-0.68^{* *}$ & $0.91^{* * *}$ \\
\hline Length & & & & & & & & & & & & & & \\
\hline 500 & 0.04 & - & -0.46 & 0.38 & -0.56 & 0.14 & 0.23 & $-0.9^{* * *}$ & $-0.83^{* * *}$ & $-0.94^{* * *}$ & 0.33 & -0.35 & $0.93^{\text {*** }}$ & $-0.76^{* *}$ \\
\hline 1500 & 0.20 & - & -0.42 & 0.38 & -0.59 & 0.18 & 0.26 & $-0.84^{* *}$ & $-0.89^{* * *}$ & $-0.98^{* * *}$ & 0.35 & -0.38 & $0.92^{* *}$ & $-0.81^{* *}$ \\
\hline 3000 & 0.24 & - & -0.40 & 0.35 & -0.55 & 0.14 & 0.28 & $-0.83^{* *}$ & $-0.89^{* *}$ & $-0.98^{* *}$ & 0.29 & -0.39 & $0.92^{* *}$ & $-0.82^{* *}$ \\
\hline \multicolumn{15}{|c|}{ 90-150 days } \\
\hline $\begin{array}{r}\text { Survival } \\
\text { System } 1\end{array}$ & -0.83 & 0.89 & -0.74 & -0.11 & $-0.95^{*}$ & 0.55 & 0.83 & $-0.97^{*}$ & -0.03 & -0.67 & 0.70 & -0.61 & 0.93 & $-0.98^{*}$ \\
\hline System 2 & -0.84 & 0.67 & -0.76 & $0.95^{*}$ & -0.80 & -0.20 & 0.78 & $-0.99^{* *}$ & -0.01 & -0.68 & 0.63 & -0.61 & 0.92 & -0.83 \\
\hline $\begin{array}{l}\text { Weight } \\
\text { System } 1\end{array}$ & 0.75 & -0.66 & $0.97^{*}$ & -0.42 & 0.66 & -0.85 & -0.48 & 0.72 & -0.43 & 0.93 & -0.58 & 0.90 & $-0.99^{* *}$ & $0.94^{*}$ \\
\hline System 2 & 0.84 & -0.38 & $0.98^{* *}$ & -0.83 & 0.32 & -0.03 & -0.33 & 0.83 & -0.48 & 0.51 & -0.90 & $0.94^{*}$ & $-0.98^{*}$ & 0.91 \\
\hline Length & & & & & & & & & & & & & & \\
\hline System 1 & 0.81 & -0.82 & 0.85 & -0.09 & 0.88 & -0.67 & -0.71 & 0.91 & -0.16 & 0.78 & -0.70 & 0.73 & $-0.98^{*}$ & $0.99^{* * *}$ \\
\hline System 2 & 0.82 & -0.49 & 0.87 & $-0.97^{*}$ & 0.60 & 0.21 & -0.57 & $0.97^{*}$ & -0.27 & 0.71 & -0.83 & 0.77 & $-0.99^{* *}$ & 0.86 \\
\hline
\end{tabular}

Number of juveniles per culture unit.

$*=p<0.05, * *=p<0.01$, no asterisk $=$ no correlation $(p>0.05)$.

\section{Length at age relationship curves}

Shell growth had different density culture (0-90 days) and different culture system (90-150 days), as a result of more rapid increase in shell length during an increase of age (Fig. 5). The relationship between shell length and each culturing duration was highly significant $(p<0.01)$. Various values of equations are shown in Table 5.

\section{Morphological development of $\boldsymbol{C}$. hainesiana}

The morphological development of $C$. hainesiana juveniles in culture (0-150 days old) is shown in Fig. 6. The early juvenile ( 0 days old) after transformation has equal length and height: i.e., $0.26 \pm 0.04 \mathrm{~mm}$, subrotund, equivalve shells with an equilateral valve, presenting the same size and shape as the glochidium. The anterior region appeared before the posterior region, and grew more rapidly until the juvenile was 90 days old, when the posterior region began to increase more than the anterior. The shell began to completely close at 20 days. The first anterior and posterior wings appear at 50 days, with the posterior wing becoming dominant relative to the anterior after 90 days. The shell was so thin during $0-90$ days of age
Table 5 Length-age relationships for freshwater pearl mussels (C. hainesiana) cultured in a laboratory (0-90 days) and in outdoors tanks (90-150 days).

\begin{tabular}{lccccc}
\hline \multicolumn{1}{c}{$b_{0}$} & $b_{1}$ & $b_{2}$ & $b_{3}$ & $r^{2}$ \\
\hline $\begin{array}{l}0-90 \text { days } \\
(n=500)\end{array}$ & & & & & \\
$500^{\dagger}$ & 0.5236 & -0.0530 & 0.0023 & $-1 \times 10^{-5}$ & 0.956 \\
1500 & 0.4694 & -0.0532 & 0.0029 & $-2 \times 10^{-5}$ & 0.967 \\
3000 & 0.4414 & -0.0494 & 0.0027 & $-2 \times 10^{-5}$ & 0.960 \\
$90-150$ days & & & & \\
$(n=1200)$ & & & & \\
System 1 & -51.302 & 0.6812 & 0 & $-5 \times 10^{-6}$ & 0.940 \\
System 2 & -47.447 & 0.6071 & 0 & $-1 \times 10^{-6}$ & 0.948 \\
\hline
\end{tabular}

$\dagger$ Number of juveniles per culture unit.

Regression equation: $L=b_{0}+b_{1} t+b_{2} t^{2}+b_{3} t^{3}$.

$L=$ shell length in mm. $t=$ age in days. $n=$ number of mussels. $r^{2}=$ coefficient of determination.

that the internal organs could be seen clearly under a microscope: e.g., the foot, gill, intestine, stomach, heart, and bundle of muscle. The first incurrent siphon and excurrent siphon appeared at 50 days. The complete adult morphology was apparent in 90-dayold mussels. 

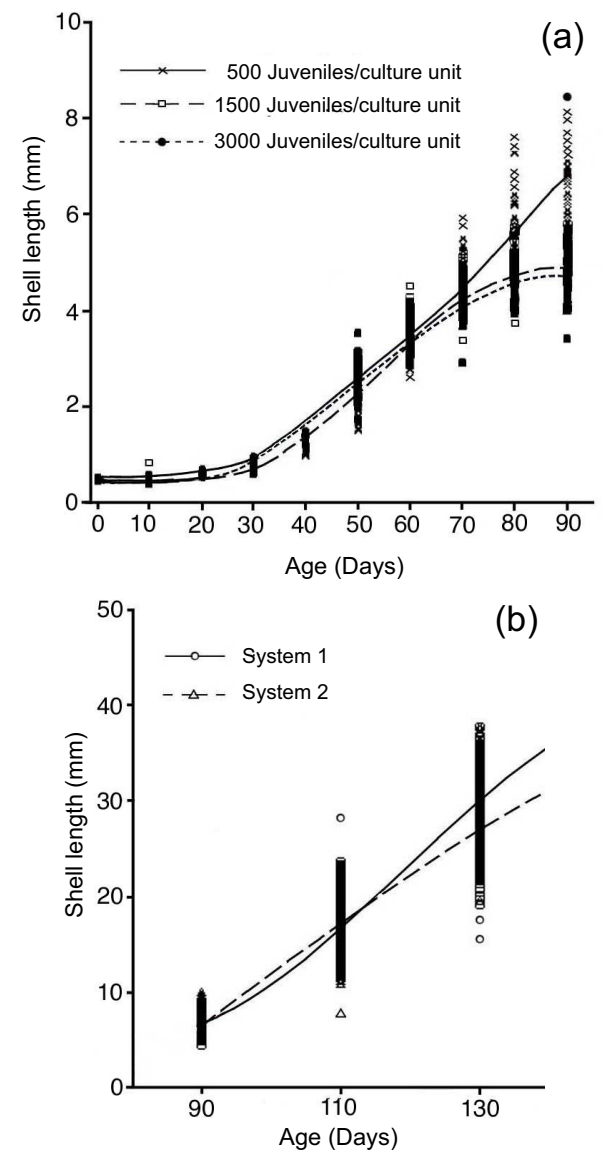

Fig. 5 Relationship curves between age and shell length in (a) different density culture and (b) different culture system.

\section{DISCUSSION}

\section{Culture of glochidia}

This study demonstrated that glochidia of $C$. hainesiana could successfully develop into a juvenile stage when cultured in artificial media and demonstrated a high rate of survival of up to $97.2 \pm 2.5 \%$, with $100 \%$ of all surviving larvae transformed into juveniles; duration of transformation was 8 days. As with cultured glochidia of the freshwater pearl mussel $H$. (L.) myersiana in the same artificial media ${ }^{14,15}$, the temperature of the incubator was different $\left(23^{\circ} \mathrm{C}\right)$. The percentage of survival of glochidia was $93 \pm 3-95 \pm 2 \%$. In addition, other freshwater pearl mussels were cultured in artificial media: Hyriopsis (Hyriopsis) bialatus ${ }^{21,23}$, Anodonta cygnea ${ }^{20}$, Ligumia recta ${ }^{11}$, and Anodonta imbecillis ${ }^{12}$. They were transformed into juveniles with survival rates of $100,60.8,48.8$, and $65.4 \%$, respectively. The important factors for transformation of glochidia into juveniles could be, successively: glochidia maturity, suitable medium (particularly fish plasma) as a growth factor for glochidia development, incubator temperature, and contamination.

\section{Culture of juveniles}

From the culture of 0-90-day-old mussels in a laboratory-scale recirculating aquaculture system, the density of cultured mussels, under otherwise similar conditions, had an effect on the rates of development and survival ${ }^{17}$. Densities of 500 mussels/culture unit had the highest value, and were (highly) significantly different from other densities $(p<0.01)$ in terms of height and survival, as opposed to a significant difference $(p<0.05)$ of the same length. The mussel diet played an important role in this experiment, which used Chlorella sp. and K. incurvata ${ }^{15,17}$. From observation of algae colour under a microscope after feeding for $30 \mathrm{~min}$, it was found that the colour of algae existing in the digestive gland, stomach, and intestine had changed from green to yellow, or orange to brown, and that such colours indicated high digestibility of algae and changing algae morphology from normal shape to debris; this resulted in increased growth of mussels and consequently high survival rates. For the study in vitro digestibility of phytoplankton a crude enzyme extract of $H$. (H.) bialatus juveniles was used. Based on the digestion of carbohydrate, protein and lipid content, it was found that Chlorella sp. 2 and $K$. incurvata are the most efficiently digested by juveniles ${ }^{19,21}$. When comparing the growth rate in length of $H$. myersiana in a report ${ }^{17}$ where they cultured with the same system in this experiment, it was found that the growth of $C$. hainesiana was closely related to the growth rate in the previous study. Cultures of 0-90-day-old C. hainesiana had values between $0.05-0.07 \mathrm{~mm} / \mathrm{d}$, as compared to growth rates of $H$. myersiana of: $0-120$ days old, $0.03-0.1 \mathrm{~mm} / \mathrm{d}^{17} ; 0-60$ days old, $0.021 \mathrm{~mm} / \mathrm{d}$; and 60-120 days old, $0.007-0.036 \mathrm{~mm} / \mathrm{d}^{15}$. Rearing of juvenile freshwater mussels, A. imbecillis, which were cultured from an artificial medium, with river water containing a diversity of plankton: namely, the genera Gonium, Anabaena, Achnanthes, Navicula, Oscillatoria, Bodo, Fragilaria, Eudorina, Stentor, Vorticella, Scenedesmus, Trachelomonas, Crucigenia, Phacus, Stephanodiscus and Chlorococcales. The oldest was 74 days, and was more than $5.1 \mathrm{~mm}$ in length (original length was $0.28 \mathrm{~mm})^{29}$. As with culture of juvenile unionids: they were four species of Lampsilis spp. and Ligumia recta. It was found that the maximum cultured age at 12 weeks showed a growth rate in length between $0.005-0.012 \mathrm{~mm} / \mathrm{d}$; growth rates depended upon several factors, such as culturing methods and diet, as well as mussel species ${ }^{30}$. 


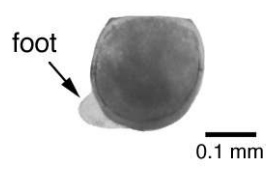

0 Days

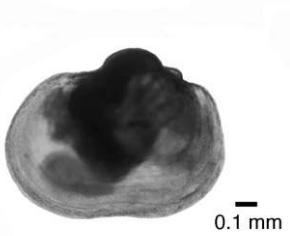

40 Days

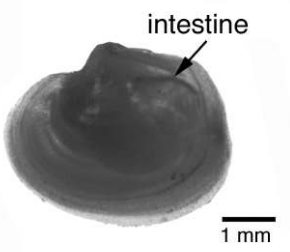

80 Days

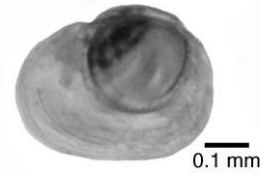

10 Days

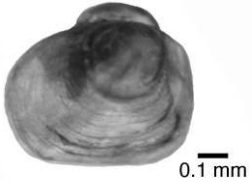

20 Days

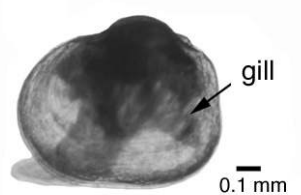

30 Days

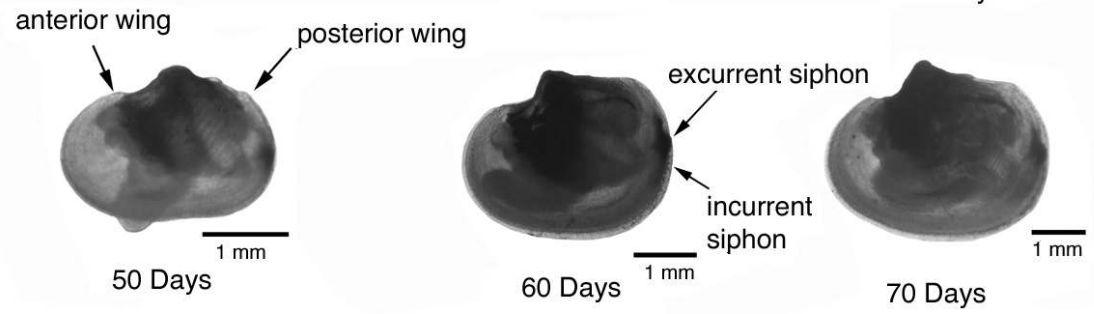

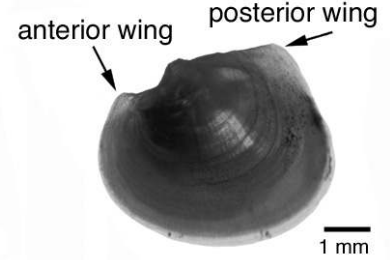

90 Days

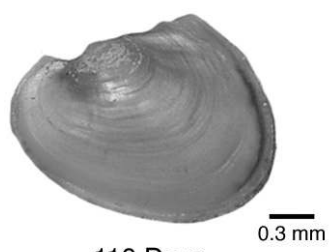

110 Days

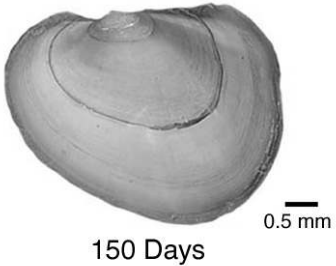

Fig. 6 Morphological development of 0-150-day-old juveniles of C. hainesiana.

When juvenile freshwater pearl mussels $H$. (L.) myersiana reared in the laboratory were transferred outdoors ${ }^{15}$, it was found that the suitable juvenile stage for outdoor culture required fully developed organs, particularly the organs for ingesting food (namely the incurrent and excurrent siphons and gills) and that their shells had closed completely. These are factors which will support increased survival and growth of juveniles. Juveniles of $C$. hainesiana began to close their shells completely when they were about 20 days old, and their organs were fully developed at 90 days; hence, this age was chosen for outdoor culture. Culture of 90-150day-old juveniles by system 1 had higher growth rates of weight, width, height and length of shell, with a significant difference from system 2; this might be due to the culturing condition of system 1 being closer to nature, as was indicated in the above studies ${ }^{31-33}$. Biofiltration using a sub-sand filter is probably the most popular ammonia removal method, with the ammonia being oxidized to nitrite and then to nitrate in the nitrification process ${ }^{34}$. As with the findings of a previous study, the ammonia content in system 1 was significantly less $(p<0.01)$ than in the system 2 . This is because in system 1 , dissolved oxygen in water could flow through a sand stratum, causing continuing oxidation of ammonia nitrogen and therefore resulting in less ammonia in the water. In system 2, however, dissolved oxygen in water could not flow through the sub-sand filter, which resulted in slower oxidation of ammonia nitrogen; this caused increased accumulation of ammonia nitrogen deeper down into the sand stratum. Therefore, a rearing system with a sub-sand filter could assist in lowering ammonia nitrogen content. Also, culturing mussels without a substrate, which resulted in very low survival ${ }^{35}$, had some important effects on pedal feeding behaviour, proper orientation of the mussels for filtering efficiency, and stability from physical disturbances.

\section{Water quality}

Water quality during each period of mussel culturing is shown in Table 3 . Water quality in the laboratory culture during $0-90$ days was mostly close to the value in a previous study ${ }^{17}$, which used the same system for culturing juveniles except that the temperature used in this study was $25^{\circ} \mathrm{C}$. Most of the water quality values that were used in culturing juveniles during 90-150 days had higher values than in culture (0-90 days), since cultured water from the resting pond was only derived from rainwater. This was accomplished by rotating some portion of water to be used by other aquatic animals and then returning the water to the original pond (closed system), which resulted in the accumulation of a high mineral content 
as seen from the high values of conductivity and total hardness. When water quality was compared between system 1 and 2, it was found that water quality was not significantly different, except total hardness and nitrate $(p<0.05)$ and total ammonia nitrogen $(p<$ 0.01 ) indicating that the culture system of freshwater pearl mussel through water sub-sand filtered (system 1) could reduce the total ammonia nitrogen content. Bacteria attached to surface area of sand particles may act as a biological filter altering ammonia nitrogen into nitrite and nitrate, respectively, which resulted in increasing higher nitrate content than in system 1 (with sub-sand filter). This is in agreement with a previous study ${ }^{36}$ in which biological filtration was used in freshwater mussel culturing system with ammonia nitrogen and nitrate values ranging from 0.001-019 and 0.35-1.9 ppm, respectively.

Culture of freshwater mussel $H$. (L.) myersiana (0-120 days old) by the same culturing system and culturing method in 0-90 days old ${ }^{17}$ of $C$. hainesiana except culturing temperature equal to $25^{\circ} \mathrm{C}$, it was found that shell length had correlation to total hardness, nitrite, silica, and calcium like in this study. When 90-150-day-old juveniles were brought for outdoor rearing, it was found that $\mathrm{pH}$, dissolved oxygen, total hardness, and calcium had correlation to survival and conductivity, $\mathrm{pH}$, total hardness, phosphorus, silica, and calcium. In a previous study $^{8}$ where juveniles of Margaritifera margaritifera were cultured from four rivers, it was found that water temperature, dissolved oxygen, conductivity, $\mathrm{pH}$, ammonia, nitrite, nitrate, phosphorus, sodium, potassium, magnesium, and calcium had correlation to growth. Moreover, it was found that $\mathrm{pH}$, alkalinity, total hardness and calcium had a significant relationship to the survival and growth rate of zebra mussel (Dreissena polymorpha) adults ${ }^{37}$.

\section{Phytoplankton communities}

In the study of 90-150-day-old cultured juveniles, it was found that system 1 had increased numbers of phytoplankton as opposed to system 2 during days $110-150$, with a significant difference $(p<0.05)$. Of the percentages of phytoplankton found in systems 1 and 2, the most was Chlorophyta (equal to $54 \pm 11$, and $55 \pm 8 \%$, respectively). This was in accordance with a study ${ }^{31}$ that found Chlorophyta to be the most prevalent in the gut contents, similar to the previous studies ${ }^{38-42}$ that found more phytoplankton than zooplankton in the gastrointestinal tracts of adult freshwater mussels. This includes a study ${ }^{15}$ using collected and cultured phytoplankton from the gastrointestinal tracts of mature $H$. myersiana from the river. Two species (Chlorella sp. and Kirchneriella incurvata) from ten species of phytoplankton were used for juvenile feeding, which conformed to the study ${ }^{19}$ in vitro digestibility of the four species of phytoplankton (Chlorella sp. 2, K. incurvata, Navicula sp., and Coccomyxa sp.) using juvenile crude enzyme extract, resulting in data on digestion of carbohydrate, protein and lipid content. The results indicated that a combination of Chlorella sp. and K. incurvata would be a suitable food formula for culture of juveniles.

\section{Length at age relationship curves}

Correlation between age and shell length when cultured in laboratory and outdoor, it was found that there was in correlation form of cubic equation and there was high correlation $(p<0.01)$ (Table 5) with coefficient of determination $\left(r^{2}\right)$ between 0.940 0.967. In the study ${ }^{43}$ which they cultured juvenile rainbow mussels (Villosa iris) with natural river water flow-through culture system until 90 days. Then they were brought to culture in natural water source for 3 years including from the study ${ }^{30}$ in culturing 8 species of freshwater mussel juvenile 8 species with the bucket rearing system for 44-72 days. In these two studies, correlation form between age and shell length was a simple linear equation but also from the study ${ }^{17}$ relating juvenile of freshwater pearl mussel, $H$. (L.) myersiana (0-120 days old) reared in the laboratory that had given correlation equation between shell length and age in cubic equation form as same as those previous study.

\section{Morphological development of $C$. hainesiana}

Morphology of shell at the beginning from 10-150 days old will be the same to full-grown adult that the shell shape is inflated since possibly during initial stage to form a curve containing new increments co-marginal and shell border. Twenty days onward certain organs slowly come to be laterally compressed, distinctly true foot that at the initial stage looks like club, the anterior portion begins to grow rapidly than the posterior portion. This is an advantage to the juvenile because the large foot is the main organ in the anterior portion and requires protection from predators and physical agents to fulfil the important function of finding food.

\section{CONCLUSIONS}

The results of this study indicate that glochidia of $C$. hainesiana could be cultured in artificial media containing mixtures of M199 and common carp plasma, and were able to develop into juveniles. The best growth and survival was produced by culturing 
0-90-day-old juveniles in a recirculating system in the laboratory at a density of 500 juveniles/culture unit, and by culturing 90-150-day-old juveniles in a subsand filter system.

Acknowledgements: This study was supported by Kasetsart University Research and Development Institute (KURDI), Kasetsart University. We thank the Department of Aquaculture, Faculty of Fisheries, Kasetsart University, for providing a pond for culturing the mussels. We are very grateful to Director of the Kanchanaburi Inland Fisheries Development Centre, Department of Fisheries and Mrs. Oodeum Meejui, whose supply of freshwater mussel C. hainesiana was greatly appreciated

\section{REFERENCES}

1. Brandt RAM (1974) The non-marine aquatic mollusca of Thailand. Arch Mollusk 105, 1-423.

2. Kovitvadhi S, Kovitvadhi U, Phasugdee S, Nagachinta A, Meejui O, Chatchavalvanich K, Siripaisarnpipat S, Wongchaisuwat A, et al (1999) Development of Freshwater Pearl Culture in Thailand. National Research Council of Thailand, Bangkok.

3. Bogan AE (1993) Freshwater bivalve extinctions (Mollusca: Unionida): a search for causes. Integr Comp Biol 33, 599-609.

4. Williams JD, Warren ML Jr, Cummings KS, Harris JL, Neves RJ (1993) Conservation status of freshwater bivalves of the United States and Canada. Fisheries 18, 6-22.

5. Williams JD, Neves RJ (1995) Freshwater mussels: a neglected and declining aquatic resource. In: LaRoe ET, Farris GS, Puckett CE, Doran PD, Mac MJ (eds) Our Living Resources: A Report to the Nation on the Distribution, Abundance, and Health of U.S. Plants, Animals, and Ecosystems. U.S. Department of the Interior, National Biological Service, Washington DC. pp 19-21.

6. Fukuhara S, Nakai I, Nagata Y (1990) Development of larvae of Anodonta woodiana (Bivalvia) parasitized on host fish. Venus 49, 54-61.

7. Panha S (1992) Infection experiment of the glochidium of a freshwater pearl mussel, Hyriopsis myersiana (Lea, 1856). Venus 51, 303-14.

8. Buddensiek V (1995) The culture of juvenile freshwater pearl mussels Margaritifera margaritifera $\mathrm{L}$. in cages: a contribution to conservation programs and the knowledge of habitat requirements. Biol Conservat 74, 33-40.

9. Uthaiwan K, Pakkong P, Noparatnaraporn N, Vilarinho L, Machado J (2003) Studies on the plasma composition of fish hosts of the freshwater mussel, Hyriopsis myersiana, with implications for improvement of the medium for culture of glochidia. Invertebr Reprod Dev 44, 53-61.
10. Hanlon SD, Neves RJ (2006) Seasonal growth and mortality of juveniles of Lampsilis fasciola (Bivalvia: Unionidae) released to a fish hatchery raceway. $A m$ Malacol Bull 21, 45-9.

11. Isom BG, Hudson RG (1982) In vitro culture of parasitic freshwater mussel glochidia. Nautilus 96, 147-51.

12. Keller AE, Zam SG (1990) Simplification of in vitro culture techniques for freshwater mussels. Environ Toxicol Chem 9, 1291-6.

13. Uthaiwan K, Noparatnaraporn N, Machado J (2001) Culture of glochidia of the freshwater pearl mussel Hyriopsis myersiana (Lea, 1856) in artificial media. Aquaculture 195, 61-9.

14. Uthaiwan K, Pakkong P, Noparatnaraporn N, Vilarinho L, Machado J (2002) Study of a suitable fish plasma for in vitro culture of glochidia Hyriopsis myersiana (Lea, 1856). Aquaculture 209, 197-208.

15. Kovitvadhi S, Kovitvadhi U, Sawangwong P, Thongpan A, Machado J (2006) Optimization of diet and culture environment for larvae and juvenile freshwater pearl mussels, Hyriopsis (Limnoscapha) myersiana Lea, 1856. Invertebr Reprod Dev 49, 61-70.

16. Kovitvadhi S, Kovitvadhi U, Sawangwong P, Machado J (2007) Morphological development of the juvenile through to the adult in the freshwater pearl mussel, Hyriopsis (Limnoscapha) myersiana, under artificial culture. Invertebr Reprod Dev 50, 207-18.

17. Kovitvadhi S, Kovitvadhi U, Sawangwong P, Machado J (2008) A laboratory-scale recirculating aquaculture system for juveniles of freshwater pearl mussel Hyriopsis (Limnoscapha) myersiana (Lea, 1856). Aquaculture 275, 169-77.

18. Kovitvadhi S, Kovitvadhi U, Sawangwong P, Trisaranuwatana P, Machado J (2009) Morphometric relationship of weight and size of cultured freshwater pearl mussel, Hyriopsis (Limnoscapha) myersiana, under laboratory conditions and earthen pond phases. Aquacult Int 17, 57-67.

19. Areekijseree M, Engkagul A, Kovitvadhi S, Kovitvadhi U, Thongpan A, Rungruangsak-Torrissen K (2006) Development of digestive enzymes and in vitro digestibility of different species of phytoplankton for culture of early juveniles of the freshwater pearl mussel, Hyriopsis (Hyriopsis) bialatus Simpson, 1900. Invertebr Reprod Dev 49, 255-62.

20. Lima P, Kovitvadhi U, Kovitvadhi S, Machado J (2006) In vitro culture of glochidia from the freshwater mussel Anodonta cygnea. Invertebr Biol 125, 34-44.

21. Supannapong P, Pimsalee T, A-komol T, Engkagul A, Kovitvadhi U, Kovitvadhi S, Rungruangsak-Torrissen K (2008) Digestive enzymes and in vitro digestibility of different species of phytoplankton for culture of the freshwater pearl mussel, Hyriopsis (Hyriopsis) bialatus. Aquacult Int 16, 437-53.

22. Srakaew N, Chatchavalvanich K, Kovitvadhi S, Kovitvadhi U, Thongpan A (2010) Histological observation on gonad development of the freshwater pearl mussel, 
Hyriopsis (Limnoscapha) myersiana. Invertebr Reprod Dev 54, 203-11.

23. Chumnanpuen P, Kovitvadhi U, Chatchavalvanich K, Thongpan A, Kovitvadhi S (2011) Morphological development of glochidia in artificial media through early juvenile of freshwater pearl mussel, Hyriopsis (Hyriopsis) bialatus Simpson, 1900. Invertebr Reprod Dev 55, 40-52.

24. Davidson JH, Helwig N, Summerfelt ST (2008) Fluidized sand biofilters used to remove ammonia, biochemical oxygen demand, total coliform bacteria, and suspended solids from an intensive aquaculture effluent. Aquacult Eng 39, 6-15.

25. APHA, AWWA, WPCF (1995) Standard Methods for the Examination of Water and Wastewater, 19th edn, American Public Health Association, American Water Works Association, Water Pollution Control Federation, Washington, DC. 2-59.

26. Prescott GW (1951) Algae of the Western Great Lakes Area: Exclusive of Desmids and Diatoms. Cranbrook Institute of Science, Bloomfield Hills, MI. pp 17-267.

27. Desikachary TV (1959) Cyanophyta. Indian Council of Agricultural Research, New Delhi. pp 77-430.

28. Wongrat L (1999) Phytoplankton [in Thai]. Faculty of Fisheries, Kasetsart Univ, Bangkok. pp 1-851.

29. Hudson RD, Isom BG (1984) Rearing juveniles of the freshwater mussels (Unionidae) in a laboratory setting. Nautilus 98, 129-35.

30. Barnhart MC (2006) Buckets of muckets: a compact system for rearing juvenile freshwater mussels. Aquaculture 254, 227-33.

31. Liberty AJ, Ostby BJ, Neves RJ (2007) Determining a suitable substrate size and sampling frequency for rearing juvenile rainbow mussels Villosa iris. $N$ Am J Aquacult 69, 44-52.

32. O'Beirn FX, Neves RJ, Steg MB (1998) Survival and growth of juvenile freshwater mussels (Unionidae) in a recirculating aquaculture system. Am Malacol Bull 14, 165-71.

33. Yeager MM, Cherry DS, Neves RJ (1994) Feeding and burrowing behaviors of juvenile rainbow mussels, Villosa iris (Bivalvia: Unionidae). J N Am Benthol Soc 13, 217-22.

34. Chen S, Ling J, Blancheton JP (2006) Nitrification kinetics of biofilm as affected by water quality factors. Aquacult Eng 34, 179-97.

35. Jones JW, Mair RA, Neves RJ (2005) Factors affecting survival and growth of juvenile freshwater mussels cultured in recirculating aquaculture systems. $N A m ~ J$ Aquacult 67, 210-20.

36. Tankersley RA, Butz SW (1998) Design, construction, and evaluation of a laboratory-scale recirculating aquaculture system for the captive care of freshwater mussels. In: Proceedings of the Conservation, Captive Care, and Propagation of Freshwater Mussels Symposium, Ohio Biological Survey. pp 127-34.

37. Hincks SS, Mackie GL (1997) Effects of pH, calcium, alkalinity, hardness, and chlorophyll on the survival, growth, and reproductive success of zebra mussel (Dreissena polymorpha) in Ontario lakes. Can J Fish Aquat Sci 54, 2049-57.

38. Gale WF, Lowe RL (1971) Phytoplankton ingestion by the fingernail clam, Sphaerium transersum (Say), in pool 19, Mississippi River. Ecology 52, 507-12.

39. Huca GA, Brennerand RR, Niveiro MH (1983) A study of the biology of Diplodon delodontus (Lamarck, 1819). Veliger 25, 51-8.

40. Binhe G (1984) Freshwater Pearl Culture. Fourth Training Course for Senior Aquaculturists in Asia and the Pacific Region. Tigbauan, Iloilo, Philippines, pp 1-20.

41. Paterson CG (1986) Particle-size selectivity in the freshwater bivalve Elliptio complanata (Lightfoot). Veliger 29, 235-7.

42. Kovitvadhi U, Nagachinta A, Aungsirirut K (2000) Species composition and abundance of plankton in the gut contents of freshwater pearl mussel, Hyriopsis (Limnoscapha) myersiana. J Med Appl Malacol 10, 203-9.

43. Beaty BB, Neves RJ (2004) Use of a natural river water flow-through culture system for rearing juvenile freshwater mussels (Bivalvia: Unionidae) and evaluation of the effects of substrate size, temperature, and stocking density. Am Malacol Bull 19, 113-20. 